\title{
Trypanocidal Activity of Isolated Naphthoquinones from Tabebuia and Some Heterocyclic Derivatives: A Review from an Interdisciplinary Study
}

\author{
Kelly C. G. De Moura ${ }^{a}$, Flávio S. Emery ${ }^{a}$, Cleverson Neves-Pinto ${ }_{b}^{a}$, Maria do Carmo F. R. Pinto ${ }^{a}$, \\ Andrea P. Dantas ${ }^{b}$, Kelly Salomão ${ }^{b}$, Solange L. de Castro ${ }^{b}$ and Antônio V. Pinto ${ }^{a_{*}}$ \\ ${ }^{a}$ Núcleo de Pesquisas em Produtos Naturais, Centro de Ciências da Saúde, Universidade Federal do Rio de Janeiro, \\ 21944-970, Rio de Janeiro - RJ, Brazil \\ ${ }^{\mathrm{b}}$ Laboratório de Biologia Celular, DUBC, Instituto Oswaldo Cruz, Fundação Oswaldo Cruz, 21045-900, \\ Rio de Janeiro - RJ, Brazil
}

\begin{abstract}
Naftoquinonas isoladas de madeiras de árvores das famílias Bignoniaceae e Verbanaceae vêem sendo estudadas de modo interdisciplinar desde a década de 70, quando Dr. Benjamin Gilbert, na UFRJ, iniciou um programa inédito sobre a química de produtos naturais voltada ao combate de doenças endêmicas. Neste artigo apresentamos a síntese de cinco naftoimidazóis decorrentes deste programa e sua ação sobre T. cruzi, agente da doença de Chagas. Revisamos também a influência da estrutura química sobre a ação tripanocida de naftoquinonas e de heteroderivados dos tipos imidazólico, oxazólico, fenoxazínico, indólico, dipirânico e ciclopentênico. A análise dos resultados corrobora a tendência de uma maior atividade tripanocida de compostos com anel imidazólico ou oxazólico ligado à estrutura naftopirânica. Dois naftoimidazóis apresentaram atividades superiores $(14,5 x$ e $34,8 x)$ ao padrão cristal violeta. Ênfase foi dada à biodiversidade da flora brasileira como ponto de partida para o desenvolvimento de uma química medicinal autônoma e criativa.
\end{abstract}

\begin{abstract}
Naphthoquinones isolated from the wood of trees of the families Bignoniaceae and Verbenaceae have been subjected to an interdisciplinary study since the seventies, when Dr. Benjamin Gilbert, at the Federal University of Rio de Janeiro, launched a program on the chemistry of natural products active against endemic diseases. In this paper we describe the synthesis of five naphthoimidazoles, derived from this program and their activity towards $T$. cruzi, the etiologic agent of Chagas disease. We also review the influence of chemical structure on trypanocidal action of naphthoquinones and of derived heterocycles with imidazole, oxazole, phenoxazine, indole, dipyrane and cyclopentene rings. The overall analysis corroborates the tendency of trypanocidal activity in compounds with an imidazole or oxazole ring linked to a naphthopyrane structure. Two naphthoimidazoles presented higher activities (14.5x and 34.8x) than the standard crystal violet. Emphasis is given to the biodiversity of the Brazilian flora as a starting point for the development of an autonomous and creative medicinal chemistry.
\end{abstract}

Keywords: naphthoquinones, heterocycles, Tabebuia, Trypanosoma cruzi, Chagas disease

\section{Introduction}

Naphthoquinones are compounds present in different families of plants; their molecular structures endow them with redox properties, which confer activity in various biological oxidative processes. In folk medicine, often originating among native Ameridian populations, plants containing naphthoquinones have been employed for the

* e mail: ventura@nppn.ufrj.br treatment of a number of diseases, including cancer ${ }^{1,2}$. The toxicity and therapeutic activities of these compounds involve the formation of oxygen reactive $\operatorname{species}^{3-5}$. The biological redox cycle of quinones can be initiated by one electron reduction leading to the formation of semiquinones, unstable intermediates that react rapidly with molecular oxygen generating free radicals. One example is the hydroxyl radical, which causes damage to biological membranes and interferes with biosynthetic pathways. Another alternative is the reduction of quinones by two electrons leading to the formation of endogenous 
hydroquinols, mediated by DT-diphorase. This enzyme is known to promote the redox cycling of 2-hydroxy-1,4naphthoquinone. This process is less harmful to the cells, and sulfatation or glucoronidation leads to inactive conjugated products easily eliminated. This latter pathway is considered a detoxification route for toxic quinones ${ }^{6-9}$.

Among bioactive naphthoquinones, we found lapachol, isolated from the heartwood of trees of Bignoniaceae and Verbanaceae families, abundant in tropical rain forests. In Brazil more than 46 types of such woods, popularly known by the name "ipês" (Tabebuia $s p$ ), have been described. Lapachol, $\alpha$-lapachone and $\beta$-lapachone have been studied by our group since the seventies, when Gilbert (NPPN/ UFRJ, Brazil) began a research on the chemistry of naphthoquinones isolated from Tabebuia species and showed their activity against Schistosoma mansoni and Trypanosoma cruzi $^{10-14}$. This was the starting point of our program on the use of quinones from the Brazilian flora against endemic diseases in Brazil.

The microbicidal activity of these naphthoquinones had been previously described by the group of Dr. Gonçalves de Lima in Recife (Pernambuco, Brazil) ${ }^{15,16}$. Following these reports, several different biological activities have been described, such as: $a$ ) cytostatic against several tumor lines ${ }^{17-22} ; b$ ) anti-inflammatory ${ }^{23} ; c$ ) bactericidal and fungicidal ${ }^{17,24-26} ; d$ ) virucidal $^{13,27,28} ; e$ ) anti-Plasmodium falciparum, a causative agent of malaria ${ }^{29}$ and $f$ ) antiSchistosoma mansoni, the agent of schistosomiasis ${ }^{12}$. In Brazil, lapachol was commercialised by the Laboratório Farmacêutico do Estado de Pernambuco (LAFEP) for use as an adjuvant in the treatment of cancer. Despite this broad spectrum of biological activities, the mechanism(s) of action of such naphthoquinones still remains unclear.

Much effort has been aimed at explaining the antitumoral activity of $\beta$-lapachone, shown to induce apoptosis $^{30-37}$. This effect has been associated with a specific inhibition of topoisomerases, enzymes involved in processes such as replication, transcription and mitosis ${ }^{38-42}$. Due to the synergistic effect of $\beta$-lapachone with taxol in a great variety of human tumour lines, the combination of these two drugs as a new approach in cancer therapy has been suggested ${ }^{43}$. It was also determined that in neoplastic cells, this quinone is a potent inhibitor of the repair of DNA damage provoked by carcinogenic substances or deleterious radiation $^{44,45}$.

The use of $\beta$-lapachone as a chemotherapeutic agent against Chagas disease has been investigated. This disease is endemic in Latin America, affecting 16-18 million people, with more than 100 million exposed to the risk of infection $^{46}$. Its etiological agent is Trypanosoma cruzi, a hemoflagellate protozoan (family Trypanosomatidae, order
Kinetoplastida $)^{47}$, whose life cycle involves obligatory passage through vertebrate (mammals, including man) and invertebrate (hematophagous triatomine bugs) hosts, in a series of stages. The trypomastigote ingested by the insect differentiates into the proliferative epimastigote form which, on reaching the posterior intestine, differentiates to metacyclic trypomastigotes. This latter form, following invasion of vertebrate host cells, undergoes differentiation into amastigotes, which after several reproductive cycles transform to trypomastigotes, the form responsible for the dissemination of the infection. In humans, after infection and a subsequent incubation period, the acute phase of Chagas disease begins, and in the absence of specific treatment, the symptoms persist for about two months, with a mortality of 2 to $8 \%$, especially among children. In the chronic phase that follows, most patients remain asymptomatic, with about $20 \%$ of the cases developing the symptoms characteristic of this phase, namely cardiac, digestive or neurologic disturbances ${ }^{48}$. The transmission of the disease occurs mainly by the vector ( 80 to $90 \%$ ), blood transfusion (5 to 20\%) and congenital routes ( 0.5 to $8 \%)^{49}$. Although recent advances in vector control in the Southern Cone countries, by initiative of the Pan American Health Organisation and World Health Organisation (WHO), have decreased the incidence of new infections ${ }^{50}$, we are still challenged by two critical problems: the treatment of chronic cases of the disease and the high level of acute cases in some Latin American countries, such as Bolivia and Mexico, where the incidence of infection in some regions reaches levels above $80 \%$ of the population ${ }^{51}$. In endemic areas the transfusional transmission of Chagas disease, due mainly to urbanisation and migration processes, represents a great threat ${ }^{52}$. For example, in 1990 in the USA, 7 million people immigrated from countries in which Chagas disease is endemic ${ }^{53}$, a preoccupying fact for the American health authorities. There is a recommendation by WHO for the use of crystal violet in hemotherapic centres in endemic areas ${ }^{54}$ to eliminate the parasite in the blood used for transfusion. This dye presents no substantial side effect, although there are reports about blood micro-agglutination and potential mutagenicity ${ }^{55}$. Its main disadvantage is the bluish colour that it confers to blood and tissues, that is not well accepted by the population.

To date, Chagas disease defies the attempts of an efficient and safe chemotherapy, with only two nitroheterocyclic drugs, nifurtimox and benznidazole, introduced in the seventies, being used for its clinical treatment. Both drugs present severe side effects and their efficacy depends on the susceptibility of different parasite populations. Already for several years only benznidazole is available 
on the market, and from a commercial point of view the pharmaceutical industry has little interest in the development of drugs for tropical diseases ${ }^{56,57}$. In this unfavourable scenario efforts have been addressed by several research groups to find more efficient and safe agents for clinical treatment ${ }^{58-60}$, and also alternative drugs for the sterilisation of blood in endemic areas.

Among several naphthoquinones isolated from Tabebuia, $\beta$-lapachone showed the highest activity against T. cruzi $^{61,62}$. In epimastigote forms it was observed that quinones induce the production of $\mathrm{H}_{2} \mathrm{O}_{2}^{63-66}$ and inhibition of nucleic acid and protein synthesis ${ }^{67}$. A promising quinone was allyl- $\beta$-lapachone active against the parasite, and since it is not inactivated by blood components, it was suggested as an alternative for crystal violet ${ }^{11,68}$.

Since Gilberts's initial concern with the chemical and biological activity of abundant naturally occurring compounds from the Brazilian flora our group has been engaged during three decades with the chemical reactivity and microbicidal activity of naphthoquinones ${ }^{10-14,27,28,69-82}$. In the present study 5 new derivatives of $\beta$-lapachone were synthesised and their activity against trypomastigotes of $T$. cruzi assayed. Since in two previous publications, were reported similar studies with 32 derivatives ${ }^{73,82}$, in this paper we present all our chemical and biological results, totalising 37 heterocyclic derivatives besides the original naphthoquinones. The relationship of their chemical structures with the corresponding biological effect is discussed.

\section{Results and Discussion}

In an ongoing program for the utilisation of naturally occurring quinones the electrophilicity of 1,2-quinoidal carbonyls with reagents containing heteroatom nucleophilic centres has been explored. These reactions transform naphthoquinones into new heterocyclic compounds. However, it is interesting to note that in the literature there are only few reports about the reaction of 1,2-quinoidal carbonyl with heteronucleophylic reagents ${ }^{73,74,78}$. Mechanistically this reaction can be rationalised by patterns described in the literature for the synthesis of heterocyclic compounds from aliphatic 1,2-dicarbonyl compounds ${ }^{84}$. A series of heterocyclic derivatives has been synthesised through the reaction of naphthoquinones with common reagents, leading to oxazoles, imidazoles, phenoxazoles and phenazine derivatives. The synthetic routes for these compounds are shown in Scheme 1.

In relation to the oxazole/imidazole type compounds, results showed that these two heterocycles are obtained as a mixture from the reaction of 1,2-naphthoquinones with aromatic aldehydes in the presence of an ammonium salt.
They could be separated by column chromatography at different ranges of polarity, naphthoxazoles by an elution mixture containing 4-6\% of ethyl acetate in hexane and naphthoimidazoles with $7-10 \%$ ethyl acetate ${ }^{73,82}$. Compounds 26, 27 and 32-34 (Scheme 4), described in the present paper, were obtained as the main products and were isolated from the reaction mixture by vacuum filtration followed by crystallisation in hexane/ethyl acetate.

Turning to the biological activities of the new compounds here synthesised, our main purpose is the screening of compounds for chemoprophylaxis in banked blood for Chagas disease and the assays were all performed with trypomastigote forms in the presence of blood. Previous biological data from the screening of a series of quinone derivatives already reported by our group ${ }^{73,82}$ are compared in order to evaluate possible structural aspects of naphthoquinones and their heterocyclic derivatives, which could be of importance in their lytic effect upon T. cruzi. The compounds are grouped according to the basic structures and range from the original quinones to naphthoxazoles, naphthoimidazoles and phenoxazine, indole, pyrane and cyclopentene derivatives (Schemes 2-5). In these schemes, the values of $\mathrm{ED}_{50} / 24 \mathrm{~h}$ (in $\mu \mathrm{mol} \mathrm{L}^{-1}$ ) are given together with the $I V$ (index of variation in relation to crystal violet) to evaluate the trypanocidal activity of these compounds.

Scheme 2 shows the original quinones (1-9). The following points can be of importance for the delineation of structural aspects associated with trypanocidal activity: a) lapachol (1) and $\beta$-lapachone (2) displayed similar activities that were somewhat higher than that of crystal violet, whereas nor- $\beta$-lapachone (3), $\alpha$-lapachone (4), and lawsone (7) were inactive; $b$ ) the Hooker degradation of $\mathbf{1}$ to nor-lapachol (6) led to reduction of activity, while the substitution of a hydroxyl group in the original quinone $\mathbf{1}$ by a methoxyl group (5) led to a 2.5 -fold increase in the trypanocidal activity; $c$ ) the introduction of an allyl group in 7, inactive against the parasite, originating O-allyllawsone (8) and C-allyl-lawsone (9), was a chemical transformation that led to compounds with trypanocidal activity similar to that of $\mathbf{1}$ and $\mathbf{2}$.

These results suggest that minor structural features such as an increase in lipophilicity, the pyran moiety (comparing compound $\mathbf{1}$ with $\mathbf{3}$ ), the presence of methoxyl groups (5 versus $\mathbf{1})$, and of an aliphatic side chain ( $\mathbf{8}$ and $\mathbf{9}$ versus $\mathbf{7})$ led to higher activity possibly associated with a better penetration of the compound through the lipid bilayer that comprises the plasma membrane of the parasite. Similar relationships were observed when the prophylaxis of schistosomiasis using these compounds was studied ${ }^{12}$. The higher activity of $\mathbf{2}$ in relation to $\mathbf{4}$ is in agreement with results published by other groups, who, although employing 


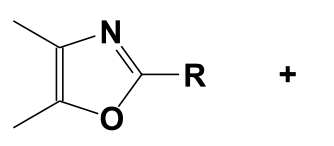

II<smiles>[R]c1nc(C)c(C)[nH]1</smiles><smiles>C1=C2CCCC2=Nc2ccccc2O1</smiles>

III

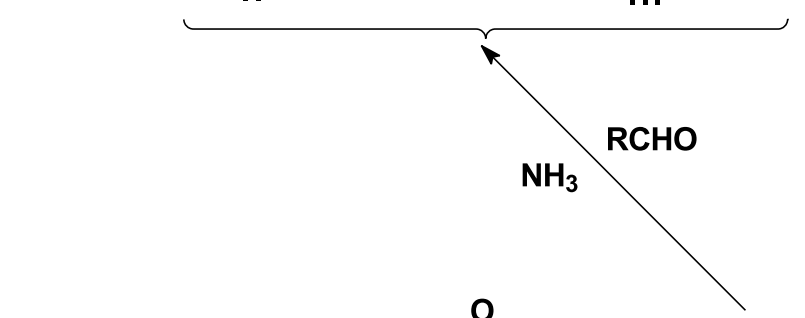<smiles>[R]C1=C(C)C(C)(O)CC1=O</smiles>

VI

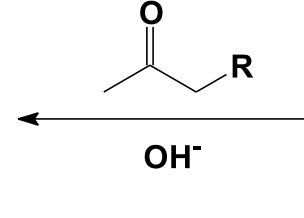

$\mathrm{OH}^{-}$<smiles>[R]C1=C(OC(C)=O)COC(C)=C1CC(C)=C(C)C(=O)O</smiles><smiles>O=C1CCCC1=O</smiles>

I

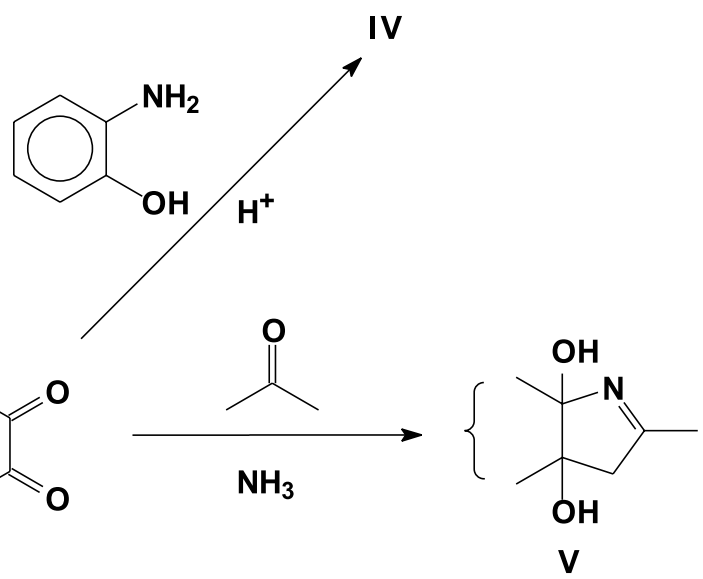

VII

Scheme 1. Schematic chemical routes to naphthoxazoles (route II), naphthoimidazoles (route III), phenoxazine (route IV), indole (route V), cyclopentene (routes VI, VIII) and pyran derivatives (route VII) from 1,2-quinones ${ }^{82}$.

different protocols, also observed that the trypanocidal activity of 1,2-quinones is higher than that of the corresponding 1,4-compounds ${ }^{14,72,76,85,86}$.

Scheme 3 shows the naphthoxazoles assayed (10-23). It can be observed that: $a$ ) The naphthoxazolic pyrane type 10 was active against $T$. cruzi $(I V=1.7)$, the corresponding furane type $\mathbf{1 8}$ was inactive. $b$ ) The introduction of an aromatic group linked to the oxazole nucleus showed a marked influence upon the trypanocidal activity. Compound $11(I V=1.9)$ with a non-substituted phenyl group and $\mathbf{1 5}(I V=2.0)$ with a methylenedioxy group led to an increase in activity in relation to crystal violet, the presence of a hydroxyl substituent led to 12, without any significant activity. c) The most active compounds of the series of the naphthoxazoles were those that retained the lapachol isoprene side chain (21-23). Again lipophilicity seems to be involved as in the case of the original quinones, both the introduction of a methoxyl group $(\mathbf{2 1}, I V=10.6)$ and of an aromatic substituent (22 IV =3.1, $23 I V=2.7)$ leading to the development of trypanocidal activity.

In summary the presence of an isoprene side chain in the naphthoxazole series and/or phenyl or methoxyl substituents (21, 22 and $\mathbf{2 3}$ versus 20 ) are factors that increase the activity against the parasite, and could be employed for further delineation of biologically active drugs of the imidazole type.

Of the eight naphthooxazoles synthesised from $\mathbf{2}$, four presented activity similar to this quinone, while four were inactive. So, with exception of the three compounds containing a isoprenyl side chain - 21, 22 and $\mathbf{2 3}$ - we did not obtain any increase in the trypanocidal activity by the chemical transformation of quinones into oxazoles. 
<smiles>CC(C)=CCC1=C(O)C(=O)c2ccccc2C1=O</smiles>

$1(410.8 \pm 53.5 ; \underline{1.3})$ lapachol<smiles>CC1(C)CC2=C(O1)c1ccccc1C(=O)C2=O</smiles>
nor- $\beta$-lapachone<smiles>COC1=C(CC=C(C)C)C(=O)c2ccccc2C1=O</smiles>

$5(164.8 \pm 30.5 ; \underline{3.3})$ methyl ether lapachol<smiles>CC1(C)CCC2=C(O1)c1ccccc1C(=O)C2=O</smiles>

$2(391.5 \pm 16.5 ; 1.4)$ $\beta$-lapachone<smiles>CC1(C)CCC2=C(O1)C(=O)c1ccccc1C2=O</smiles>

$4(>4800)$ orlapachone<smiles>CC(C)=CC1=C(O)C(=O)c2ccccc2C1=O</smiles>

$6(1280.6 \pm 167.2 ; 0.4)$ nor-lapachol<smiles>O=C1C=C(O)C(=O)c2ccccc21</smiles>

7 (>2500) lawsone<smiles>C=CCOC1=CC(=O)c2ccccc2C1=O</smiles>

$8(420.7 \pm 71.2 ; 1.3)$ O-allyl lawsone<smiles>C=CCC1=C(O)C(=O)c2ccccc2C1=O</smiles>

$9(330.7 \pm 62.4 ; \underline{1.6})$ Gallyl lawsone

Scheme 2. Naphthoquinones assayed ${ }^{73}$. The numbers in parentheses correspond to the values of $\mathrm{ED}_{50} / 24 \mathrm{~h}$ expressed in $\mu$ mol $\mathrm{L}^{-1}$, for the lytic effect on trypomastigote forms of $T$. cruzi and underlined, the index of variation $(I V)$ in relation to crystal violet $\left(\mathrm{ED}_{50} / 24 \mathrm{~h}=536.0 \pm 1.0 \mu \mathrm{mol} \mathrm{\textrm {L } ^ { - 1 }}\right)$.

Turning to the naphthoimidazoles (24-36) all of the derivatives which possess aromatic groups attached to the imidazole ring are now considered (Scheme 4). The phenyl group does not appear to be relevant to activity in view of the fact that none of these compounds ( $\mathbf{2 6}$ to $\mathbf{3 5}$, IV ranging from 0.3 to 2.1 ) was more active than the unsubstituted derivative (25) $(I V=14.5)^{73}$. However, it is important to note that compounds $28(I V=2.1), \mathbf{3 1}(I V=1.8), \mathbf{3 2}(I V$ $=2.2)$ and $\mathbf{3 3}(I V=1.4)$ are more active than the standard drug crystal violet. Another derivative with a 3-indolyl group linked to the imidazole ring (24) showed the highest activity against $T$. cruzi $(I V=34.8)$ of all the 37 compounds prepared. In the naphthoimidazole series, only one derivative was synthesised (36) from $\mathbf{3}$, but similarly to the original quinone, it had little activity against the parasite.

An overall analysis based only upon the type of the heterocyclic nucleus (oxazole versus imidazole) attached to the naphthalene backbone (Schemes 3 and 4), shows 

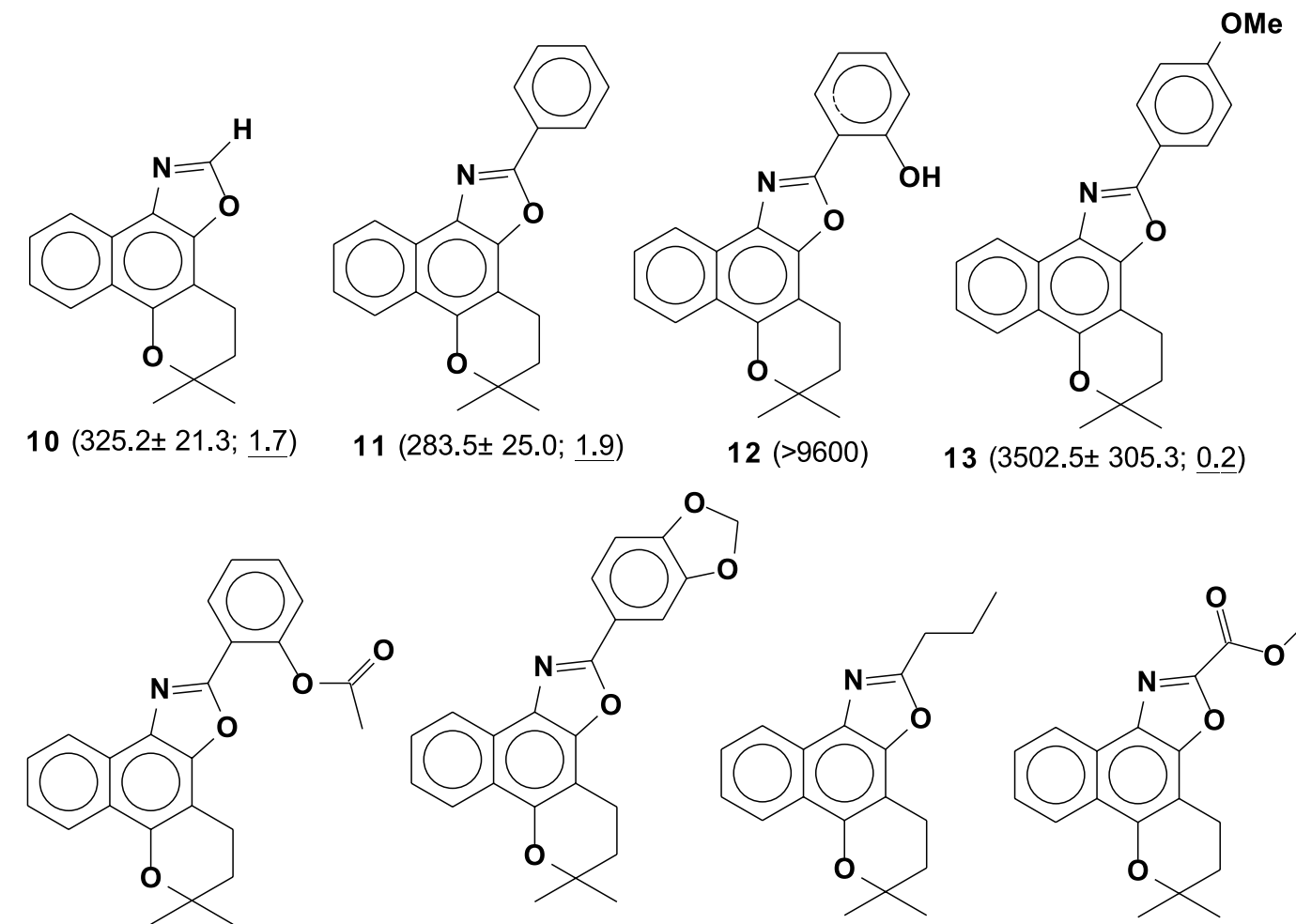<smiles>CC1(C)CCc2c(c3c(c4ccccc24)OC(C)(C)CC3)O1</smiles><smiles>CCCc1nc2c(o1)c1c(c3ccccc32)OC(C)(C)CC1</smiles><smiles>CCOC(=O)c1nc2c(o1)c1c(c3ccccc32)OC(C)(C)CC1</smiles>

$14(1641.3 \pm 147.0 ; \underline{0.3})$

$15(269.5 \pm 46.5 ; \underline{2.0})$

$16(351.4 \pm 12.4 ; \underline{1.5})$

$17(>4800)$<smiles>CC1(C)Cc2c(c3ccccc3c3ncoc23)O1</smiles>

$18(>2500)$<smiles></smiles>

$21(49.5 \pm 1.4 ; 10.8)$<smiles>CC1(C)Cc2c(c3ccccc3c3nc(-c4ccccc4O)oc23)O1</smiles>

$19(>2500)$<smiles>CC(C)=CCc1c(O)c2ccccc2c2nc(-c3ccccc3)oc12</smiles>

$22(171.9 \pm 51.2 ; \underline{3.1})$<smiles>CC(C)=CCc1c(O)c2ccccc2c2ncoc12</smiles>

$20(>2500)$<smiles>COc1c(CC=C(C)C)c2oc(-c3ccccc3)nc2c2ccccc12</smiles>

$23(197.3 \pm 25.8 ; \underline{2.7})$

Scheme 3. Naphthoxazoles assayed ${ }^{73,82}$. The numbers in parentheses correspond to the values of $\mathrm{ED}_{50} / 24 \mathrm{~h}$ expressed in $\mu$ mol $\mathrm{L}^{-1}$, for the lytic effect on trypomastigote forms of $T$. cruzi and underlined, the index of variation $(I V)$ in relation to crystal violet $\left(\mathrm{ED}_{50} / 24 \mathrm{~h}=536.0 \pm 1.0 \mu \mathrm{mol} \mathrm{L} \mathrm{L}^{-1}\right)$.

that in general the imidazole compounds $25(I V=14.5)$ and $\mathbf{2 8}(I V=2.1)$ were more active than the corresponding oxazoles $\mathbf{1 1}(I V=1.9)$ and $\mathbf{1 3}(I V=0.2)$ with one exception - $15(I V=2.0)$ compared with the imidazole $35(I V=0.3)$. A consistent observation is that all the furane derivatives
18, 19 and 36, originated from 3 , are inactive, as is the original quinone (Scheme 1).

In Scheme 5 are displayed other heterocyclics with phenoxazine (37), indole (38), cyclopentene (39-44) and pyrane $(\mathbf{4 5 , 4 6 )}$ structures, whose full synthesis and 


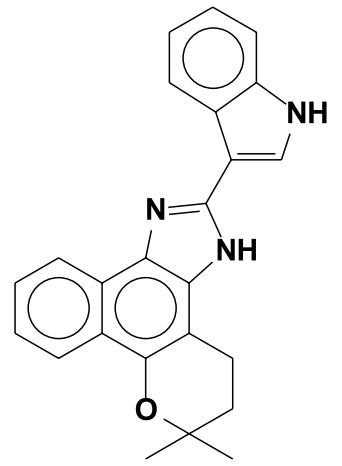

$24(15.4 ; \underline{34.8})$<smiles>CC1(C)CCc2c(c3ccccc3c3nc(-c4ccccc4)[nH]c23)O1</smiles>

$25(37.0 \pm 0.7 ; \underline{14.5})$
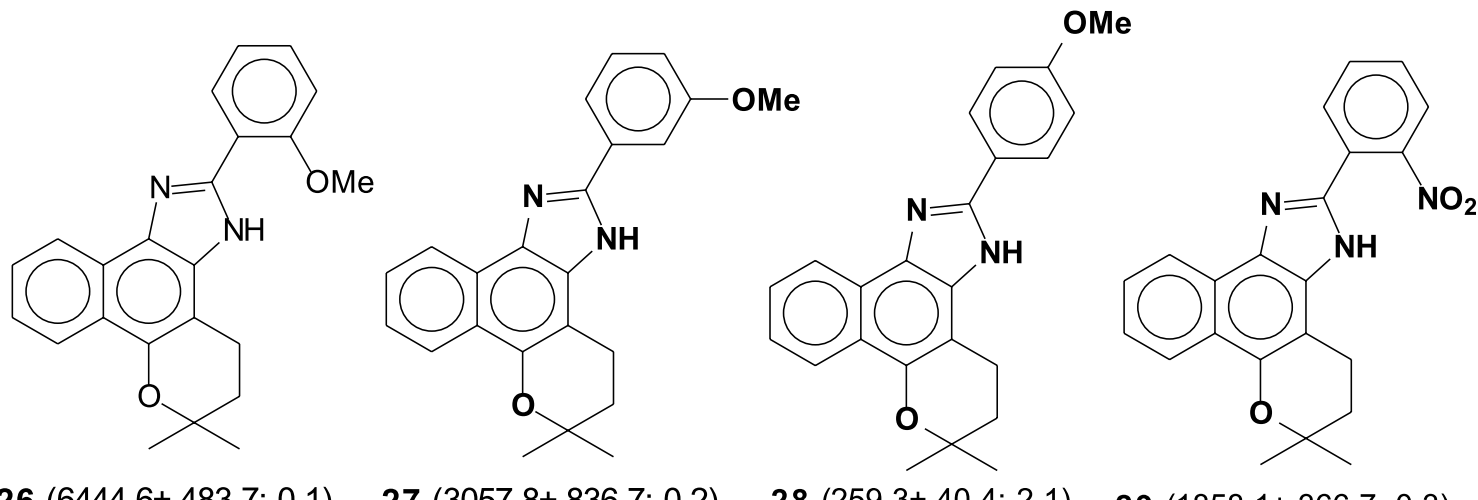

$26(6444.6 \pm 483.7 ; \underline{0.1})$

$27(3057.8 \pm 836.7 ; \underline{0.2})$

$28(259.3 \pm 40.4 ; \underline{2.1})$

$29(1858.1 \pm 366.7 ; \underline{0.3})$

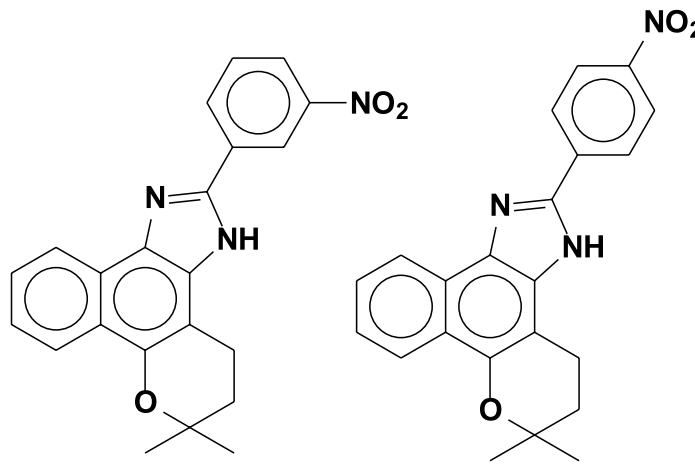

$30(579.3 \pm 52.5 ; \underline{0.9}) \quad 31(303.6 \pm 12.2 ; \underline{1.8})$

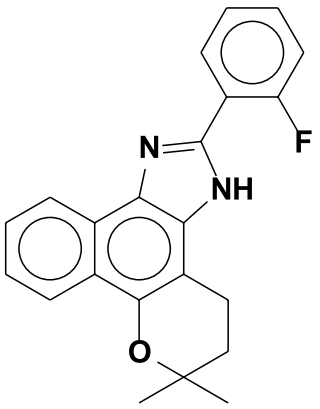

$32(243.3 ; 2.2)$

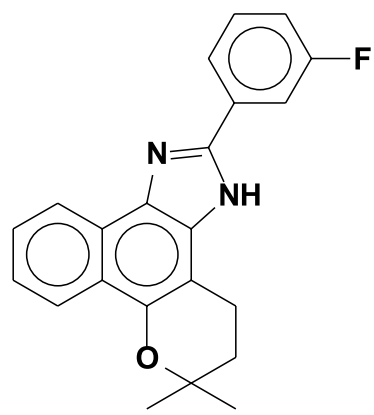

$33(372.0 ; 1.4)$<smiles>CC1(C)CCc2c(c3ccccc3c3nc(-c4cccc(Cl)c4)[nH]c23)O1</smiles>

$34(1064.2 ; \underline{0.5})$<smiles>CC1(C)CCc2c(c3ccccc3c3nc(-c4ccc5c(c4)OCO5)[nH]c23)O1</smiles>

$35(1850.5 ; \underline{0.3})$

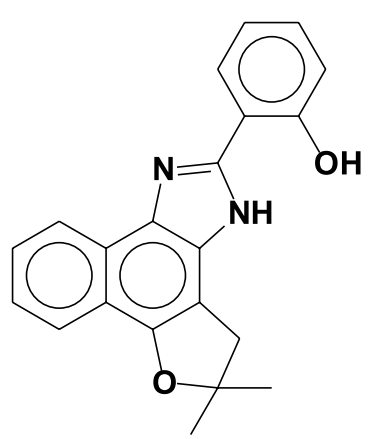

$36(4455.5 \pm 465.8 ; \underline{0.1})$

Scheme 4. Naphthoimidazoles assayed (present work and refs 73 and 82). The numbers in parentheses correspond to the values of $\mathrm{ED}_{50} / 24 \mathrm{~h}$ expressed in $\mu \mathrm{mol} \mathrm{L}^{-1}$, for the lytic effect on trypomastigote forms of $T$. cruzi and underlined, the index of variation $(I V)$ in relation to crystal violet $\left(\mathrm{ED}_{50} / 24 \mathrm{~h}=\right.$ $\left.536.0 \pm 1.0 \mu \mathrm{mol} \mathrm{L}^{-1}\right)$. 
<smiles>CC(C)=CCc1c2oc3ccccc3nc-2c2ccccc2c1=O</smiles>

$37(>4000)$<smiles>CC(=O)C1=C2C3=C(OC(C)(C)C3)c3ccccc3C2(O)CC1=O</smiles>

39 (nd)<smiles>CCOC(=O)C1=C2C3=C(OC(C)(C)C3)c3ccccc3C2(O)CC1=O</smiles>

$40(>4000)$<smiles></smiles>

$43(>4000)$<smiles>CC(=O)OC1=C(C(C)=O)c2c(c3c(c4ccccc24)OC(C)(C)C3)OC1</smiles>

45 (nd)<smiles>CC1=NC2(O)c3ccccc3C3=C(CCC(C)(C)O3)C2(O)C1</smiles>

$38(1216.7+349.1 ; \underline{0.4})$<smiles>CC(=O)C1=C2C3=C(OC(C)(C)CC3)c3ccccc3C2(O)CC1=O</smiles>

$41(>4000)$<smiles>CCOC(=O)C1=C2C3=C(OC(C)(C)CC3)c3ccccc3C2(O)CC1=O</smiles>

$42(56.1+15.5 ; \underline{9.6})$<smiles></smiles>

$44(786.9+80.0 ; \underline{0.7})$<smiles>CC(=O)OC1=C(C(C)=O)c2c(c3c(c4ccccc24)OC(C)(C)CC3)OC1</smiles>

46 ( $>4000)$

Scheme 5. Other heterocycles obtained from the naphthoquinones assayed ${ }^{82}$. The numbers in parentheses correspond to the values of $\mathrm{ED}_{50} / 24 \mathrm{~h}$ expressed in $\mu \mathrm{mol} \mathrm{L}^{-1}$, for the lytic effect on trypomastigote forms of $T$. cruzi and underlined, the index of variation (IV) in relation to crystal violet $\left(\mathrm{ED}_{50}{ }^{\prime}\right.$ $\left.24 \mathrm{~h}=536.0 \pm 1.0 \mu \mathrm{mol} \mathrm{L}^{-1}\right)$.

trypanocidal activity have been previously published ${ }^{82}$. Among the cyclopentene derivatives (39-44) obtained by the reaction of $\mathbf{2}$ or $\mathbf{3}$ with aliphatic acetoesters (Table 2), only 42, obtained from ethyl acetoacetate, was active, with a 9.6-fold increase in activity in comparison with crystal violet. Of the two pyrane compounds - $\mathbf{4 5}$ and $\mathbf{4 6}$ - obtained from 39 and $\mathbf{4 1}$, respectively, only the second one was assayed against $T$. cruzi (46), but showed no activity. Since we have few compounds belonging to a uniform group, it was not possible to indicate any correlation between these structures and their trypanocidal activity. However, among the cyclopentene derivatives, two correlations may be tentatively made: $a$ ) a compound with a pyrane ring (42) shows higher activity than the corresponding one with a 
furane ring $(40) ; b)$ the presence of a carboxyethyl group on the dihydrofuranone ring (42) increases the trypanocidal activity in relation to the corresponding acetyl compound (41).

The inactivation of the trypanocidal action of 2 (Scheme 2) by blood has been previously reported ${ }^{11}$. Thus, in the case of this quinone and also of the newly synthesised naphthoimidazoles $(\mathbf{2 6}, \mathbf{2 7}, \mathbf{3 2}-\mathbf{3 4})$ (Scheme 4) concomitant experiments were performed in the absence of blood. In the case of 2 the $\mathrm{ED}_{50} / 24 \mathrm{~h}$ decreased from $391.5 \pm 16.5$ to $97.8 \pm 2.2 \mu \mathrm{mol} \mathrm{L}-1$, indicating a 4-fold increase of activity when the experiment was performed in absence of blood in comparison with the standard procedure, using 5\% blood. For the naphthoimidazoles (Scheme 4) the increase in the trypanocidal activity was between threefold (compound 32) to 252 times (compound 26), indicating that blood components can protect trypomastigotes against the effects of $\mathbf{2}$ and of its derivatives. It was previously suggested that the inactivation of naphthoquinones was due to their interaction with blood components, reducing the availability of the free compound ${ }^{11}$. This inactivation could also be explained by the reduction of 1,2-naphthoquinones to hydroquinones mediated by the host DT-diaphorase, the hydroquinones being converted to non-toxic conjugates ${ }^{9}$. Another possibility for inactivation by blood could be a covalent chemical link between quinoidal carbonyl and free $\mathrm{NH}_{2}$ residues of proteins. This latter reaction has been confirmed by our group ${ }^{69-71,74-78}$, but knowledge about loss of the activity of quinones and their heterocyclic derivatives requires more investigation. The mechanisms of deactivation by blood could be different for these diverse groups of compounds.

Summarizing, of the oxazole and imidazole derivatives, about $50 \%$ showed activity higher than crystal violet, while the other half was inactive. However, one point merits attention; while all the oxazole compounds considered active (Scheme 3 ) presented a similar range of activity (IV between 1.5 and 10.8 ), in the imidazole group two compounds showed pronounced activity - $24(I V=34.8)$ and $25(I V=14.5)$. This suggests that the introduction of new aromatic structures and particularly indole groups, at the imidazole ring, could lead to compounds with high trypanocidal activity. The higher activity of the imidazoles may be related to the fact that several substances described as trypanocidal agents, such as benznidazole, contain basic imidazole moieties ${ }^{87-92}$. The structure of these heterocycles does not endow them with the capacity of free radical generation by a biological oxyreductive cycle as occurs with naphthoquinones ${ }^{62,63,65,66,93}$. Although we have no information about the mechanism of action of the compounds here described it is possible to suppose that due to their polycyclic planar topology, these derivatives are potential candidates as DNA intercalating agents. This group of drugs has not been extensively explored in the experimental chemotherapy of Chagas disease, with only few examples ${ }^{94-98}$.

Experiments are under way aiming to analyse the effect of compounds $\mathbf{2 4}$ and $\mathbf{2 5}$ on amastigote forms of T. cruzi interiorised in host cells and the cytotoxicity to mammalian cells, which may provide some evidence as to the mechanism of action against the parasite.

\section{Concluding Remarks}

Readily available quinones from Tabebuia species (ipê) and the synthetic alternative routes to heterocycles already studied by our group ${ }^{12,69-72,74-78}$ may be considered promising starting points for medicinal chemistry studies in other fields of antimicrobial chemotherapy. The present study also reinforces the potential of the Brazilian flora, biodiversity in the pursue of new drugs to fight against tropical diseases.

\section{Experimental}

\section{Chemistry}

Melting points were determined in a capillary Thomas Hoover apparatus and are uncorrected. ${ }^{1} \mathrm{H}$ and ${ }^{13} \mathrm{C}$ NMR spectra were recorded using a Varian Gemini 200 and a Brucker $200 \mathrm{MHz}$ spectrophotometers, in the solvents indicated, with TMS as internal standard at room temperature. Chemical shifts $(\delta)$ are given in ppm and coupling constants $(J)$ in Hz. Infrared spectra were recorded on a Perkin-Elmer 783 spectrophotometer and Nicolet FTIR in $\mathrm{KBr}$ pellets or liquid films. UV spectra were obtained on a Shimadzu UV-1601 spectrophotometer in ethanol or hexane. The mass spectra were obtained at $70 \mathrm{eV}$ in a VG Autospec apparatus. The fragments were described as a relation between atomic mass units and the charge $(\mathrm{m} / \mathrm{z})$ and the relative abundance in percentage of the base peak intensity.

Column chromatography was performed using silica gel (0.063-0.2 mm/70-230 mesh). Visualisation of the compounds on the chromatographic plates was made under ultraviolet light, exposure to iodine vapour or spraying with $2 \%$ cerium sulphate in $1 \mathrm{~mol} \mathrm{~L}^{-1}$ sulphuric acid, followed by gentle heating. 


\section{Original quinones}

Lapachol (1) was extracted from the heartwood of Tabebuia spp. (Tecoma) and purified by recrystallization from ethanol, according to the procedure previously described $^{70}$. $\beta$-Lapachone (2) was obtained through cyclisation in acid medium of the lapachol isoprenyl side chain, in the presence of sulphuric acid ${ }^{69}$.

Synthesis of new naphthoimidazolic derivatives from $\beta$ lapachone (2)

To a solution of $\mathbf{2}(242 \mathrm{mg}, 1.1 \mathrm{mmol})$ in acetic acid (6
$\mathrm{mL})$, the desired aldehyde (see below) was added $(2.5$ $\mathrm{mmol}$ ) and the mixture gently heated to $70^{\circ} \mathrm{C}$; ammonium acetate $(1.2705 \mathrm{~g}, 16.5 \mathrm{mmol})$ was slowly added and the reaction was monitored by thin layer chromatography. Then the material was brought to room temperature and added to water at $5^{\circ} \mathrm{C}$. The precipitate obtained was filtered, dried and purified by column chromatography on silica gel, using as eluent a mixture of hexane/ethyl acetate, with the ratio 9:1, with increasing polarity gradient.

Compounds 26, 27, 32, 33 and 34 (Tables 1 and 2) were obtained as the main products. They were purified by crystallisation in hexane/ethyl acetate (9:1).

The aldehydes employed, the reaction time for each

Table 1. Physical and spectral data of compounds 26, 27, 32, 33 and 34.

\begin{tabular}{|c|c|c|c|c|c|}
\hline \# & $\begin{array}{c}\mathrm{UV}(\mathrm{EtOH}) \\
\lambda_{\max } \mathrm{nm}(\log \mathrm{e})\end{array}$ & $\begin{array}{c}\mathrm{IR} \\
v_{\max } / \mathrm{cm}^{-1}(\mathrm{KBr})\end{array}$ & $\begin{array}{l}\text { MS }(70 \mathrm{eV}) \\
m / z(\%)\end{array}$ & $\begin{array}{c}{ }^{1} \mathrm{H} \text { NMR }(200 \mathrm{MHz})^{\mathrm{a}} \\
\delta_{\mathrm{H}}\end{array}$ & $\begin{array}{c}{ }^{13} \mathrm{C} \text { NMR }(50 \mathrm{MHz})^{\mathrm{a}} \\
\delta_{\mathrm{C}}\end{array}$ \\
\hline 26 & $\begin{array}{l}348(4.28) ; 293(4.23) \\
252(4.40) ; 219(4.52)\end{array}$ & $\begin{array}{l}2999 ; 2995 ; 1595 ; 1582 \\
1485 ; 1436 ; 1384 ; 1323 \\
1260 ; 1159 ; 1121 ; 1054 \\
765 ; 714\end{array}$ & $\begin{array}{l}358(41) ; 342(2) ; 315(8) ; \\
303(36) ; 302(100) ; 287 \\
(2) ; 272(4) ; 259(7)\end{array}$ & $\begin{array}{l}8.5(\mathrm{~d}, 1 \mathrm{H}) ; 8.2(\mathrm{dd}, 1 \mathrm{H}) \\
7.87(\mathrm{dd}, 1 \mathrm{H}) ; 7.84(\mathrm{~m}, \\
1 \mathrm{H}) ; 7.5(\mathrm{~m}, 1 \mathrm{H}) ; 7.4-7.3 \\
(\mathrm{~m}, 2 \mathrm{H}) ; 7.0(\mathrm{~m}, 1 \mathrm{H}) ; 3.9 \\
(\mathrm{~s}, 3 \mathrm{H}) ; 3.1(\mathrm{t}, 2 \mathrm{H}) ; 1.9(\mathrm{t}, \\
2 \mathrm{H}) ; 1.4(\mathrm{~s}, 6 \mathrm{H})\end{array}$ & $\begin{array}{l}161.0(\mathrm{~s}) ; 148.0(\mathrm{~s}) ; 146.0 \\
(\mathrm{~s}) ; 133.3(\mathrm{~s}) ; 133.0(\mathrm{~s}) ; \\
131.1(\mathrm{~s}) ; 130.6(\mathrm{~d}) ; 126.5 \\
(\mathrm{~d}) ; 124.6(\mathrm{~s}) ; 124.2(\mathrm{~d}) ; \\
123.5(\mathrm{~d}) ; 119.2(\mathrm{~d}) ; 118.2 \\
(\mathrm{~s}) ; 115.5(\mathrm{~d}) ; 114.0(\mathrm{~d}) ; \\
112.0(\mathrm{~d}) ; 102.0(\mathrm{~s}) ; 75.5 \\
(\mathrm{~s}) ; 55.6(\mathrm{q}) ; 32.7(\mathrm{t}) ; 26.9 \\
(\mathrm{q}) ; 26.9(\mathrm{q}) ; 18.5(\mathrm{t})\end{array}$ \\
\hline
\end{tabular}

$27 \quad 350$ (4.31); 292 (4.19); $3434 ; 3187 ; 3113 ; 3067$; 253 (4.40); $219(4.52) \quad 2970 ; 2940 ; 2366 ; 1717$; $1581 ; 1470 ; 1367 ; 1250$; $1158 ; 1120 ; 1021 ; 951$; $761 ; 747$
$358(84) ; 343(3) ; 315(11)$ 303 (41); 302 (100); 287 (8); 284 (64); 272 (12); 259 (14) $11.2(\mathrm{sl}, 1 \mathrm{H}) ; 8.5(\mathrm{~d}, 1 \mathrm{H})$ $8.4(\mathrm{~d}, 1 \mathrm{H}) ; 8.2(\mathrm{~d}, 1 \mathrm{H}) ; 7.5$ $(\mathrm{m}, 1 \mathrm{H}) ; 7.4(\mathrm{~m}, 2 \mathrm{H}) ; 7.1$ $(\mathrm{m}, 2 \mathrm{H}) ; 4.0(\mathrm{~s}, 3 \mathrm{H}) ; 3.0(\mathrm{t}$ $2 \mathrm{H}) ; 1.9(\mathrm{t}, 2 \mathrm{H}) ; 1.4(\mathrm{~s}, 6 \mathrm{H})$ $157.4(\mathrm{~s}) ; 155.0(\mathrm{~s}) ; 139.0$ (s); 133.3 (s); 133.2 (s); 131.3 (s); 130.9 (d); 130.1 (d); 125.9 (s); 124.9 (s); 124.1 (d); 124.0 (d); 123.2 (d); 121.1 (d); 121.8 (d); $112.4(\mathrm{~d}) ; 104.0(\mathrm{~s}) ; 75.0$ (s); $56.2(\mathrm{q}) ; 32.7(\mathrm{t}) ; 26.9$ (q); 26.9 (q); 19.3 (t)

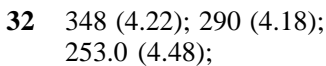
$223(4.48)$
$3423 ; 3152 ; 3107 ; 3064$ 2974; 2948; 2929; 1599; $1583 ; 1462 ; 1444 ; 1252$; $1223 ; 1160 ; 1120 ; 1056$ $952 ; 880 ; 772 ; 758 ; 733$

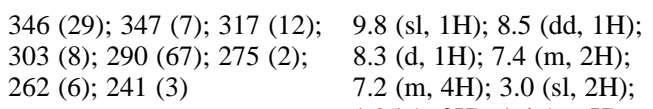

346 (29); 347 (7); 317 (12); 9.8 (sl, 1H); 8.5 (dd, 1H); 303 (8); 290 (67); 275 (2); $\quad 8.3$ (d, 1H); 7.4 (m, 2H); $262(6) ; 241(3)$

$162.1(\mathrm{~s}) ; 157.2(\mathrm{~s}) ; 145.7$ (s); 143.4 (s); 133.3 (s); 130.8 (s); 130.1 (d); 129.4 (d); 125.9 (d); 124.9 (d); 123.8 (d); 123.4 (s); 122.6 (d); $120.9(\mathrm{~d}) ; 117.8(\mathrm{~s})$; 116.0 (s); 103.8 (s); 74.5 $(\mathrm{s}) ; 31.9(\mathrm{t}) ; 26.6(\mathrm{q}) ; 26.6$ (q); $18.5(\mathrm{t})$

1416 (s); 1412 (s); 1404 (s); 1304 (s); 1295 (d); 1294 (s); 1293 (s); 1292 (d); 1291 (d); 1286 (d); 1277 (s); 1231 (d); 1229 (d); 1218 (d); 1218 (d); 1217 (d); 1213 (d); 1038 (s); 915 (d); 745 (s); 325 (t); $260(\mathrm{q}) ; 220(\mathrm{t})$
$34 \quad 354$ (4.41); 296 (4.31); $3095 ; 3074 ; 3051 ; 2973 ; \quad 364$ (12); 363 (10); 362 253 (4.54); $210(4.63)$ (39); 347 (2.5); 319 (6); $1485 ; 1473 ; 1458 ; 1212$; 1159; 1121; 1056; 969; 954; 885; 866; 766; 713

\section{7 (2); 303 (8); 290 (100);} $275(2) ; 261(5)$ 306 (100); 292 (1); $271(4) ; 242(7)$ $8.5(\mathrm{~d}, 1 \mathrm{H}) ; 82(\mathrm{~m}, 1 \mathrm{H}) ; 8.1$ $(\mathrm{d}, 2 \mathrm{H}) ; 7.5(\mathrm{~m}, 1 \mathrm{H}) ; 7.4$ $(\mathrm{m}, 3 \mathrm{H}) ; 3.0(\mathrm{t}, 2 \mathrm{H}) ; 1.9(\mathrm{t}$, $2 \mathrm{H}) ; 1.4(\mathrm{~s}, 6 \mathrm{H})$
$1446 ; 1367 ; 1259 ; 1159$; 1121; 1056; 970; 951; $778 ; 721$ $7.15(\mathrm{~m}, 1 \mathrm{H}) ; 3.1(\mathrm{t}, 2 \mathrm{H})$ $2.0(\mathrm{t}, 2 \mathrm{H}) ; 1.4(\mathrm{~s}, 6 \mathrm{H})$
148.2 (s); 146.0 (s); 135.1 (s); 133.2 (s); 133.2 (s); 131.2 (d); 130.8 (s); 128.6 (d); 126.6 (d); 126.4 (d); 125.1 (d); 124.9 (s); 124.6 (s); 124.4 (d); 123.3 (d); 122.1 (d); 103.1 (s); 75.1 (s); $32.7(\mathrm{~s}) ; 32.7(\mathrm{t}) ; 26.9$ (q); 26.9 (q); 19.7 (t) 
Table 2. Reagents and reaction conditions for the synthesis of the heterocycles from naphthoquinones

\begin{tabular}{|c|c|c|c|c|c|c|c|}
\hline \# & $\mathrm{Q}^{\mathrm{a}}$ & reagents & products & temp & time & $\begin{array}{l}\text { yield } \\
(\%)^{c}\end{array}$ & $\begin{array}{c}\mathrm{mp} \\
\left({ }^{\circ} \mathrm{C}\right)\end{array}$ \\
\hline & & naphthooxazoles (route II) ${ }^{\text {b }}$ & & & & & \\
\hline $\mathbf{1 0}$ & 2 & Glycine/Pyridine & 4,5-Dihydro-6,6-dimethyl-6H-pyran[2’,3’,4-3]naphtho[2,1-d] oxazole & refl $^{\mathrm{d}}$ & $16 \mathrm{~h}$ & 41 & 120 \\
\hline 11 & 1 & Benzaldehyde/ $/ \mathrm{NH}_{4} \mathrm{OAc}$ & 4,5-Dihydro-6,6-dimethyl-6H-2-phenyl-pyran[2',3'-4-3]naphtho[1,2-d] oxazole & refl & $2 \mathrm{~d}$ & 26 & 160 \\
\hline 12 & 2 & 2-Hydroxybenzaldehyde/ $\mathrm{NH}_{4} \mathrm{OAc}$ & 4,5-Dihydro-6,6-dimethyl-6H-2-(2'-hydroxyphenyl)-pyran $\left[2^{\prime}, 3^{\prime}-4,3\right]$ naphtho[1,2-d] oxazole & refl & $1 / 4 \mathrm{~h}$ & 46 & 206 \\
\hline 13 & 2 & 4-Methoxybenzaldehyde/ $\mathrm{NH}_{4} \mathrm{OAc}$ & 6,6-Dimethyl-4,5-dihydro-6H-2-(4'-methoxyphenyl)-pyran[b-4,3]naphtho[1,2-d] oxazole & refl & $1 \mathrm{~h}$ & 30 & 149 \\
\hline 14 & 12 & Acetic anhydride/pyridine & 6,6-Dimethyl-4,5-dihydro-6H-2-(2'-acetoxyphenyl)-pyran[b-4,3]naphtho[1,2-d] oxazole & $\mathrm{rt}^{\mathrm{e}}$ & $1 \mathrm{~d}$ & 98.9 & 130 \\
\hline 15 & 2 & 3,4-Methylenedioxybenzaldehyde/ $\mathrm{NH}_{4} \mathrm{OAc}$ & 6,6-Dimethyl-4,5-dihydro-6H-2-(3',4'-methylenedioxy)-pyran[b-4,3]naphtho[1,2-d] oxazole & refl & $1.5 \mathrm{~h}$ & 12 & 214 \\
\hline 16 & 2 & n-Butyraldehyde/ $\mathrm{NH}_{4} \mathrm{OAc}$ & 6,6-Dimethyl-4,5-dihydro-2-(n-propyl)-6H-pyran[b-4,3]naphtho[1,2-d] oxazole & refl & $96 \mathrm{~h}$ & 49 & 97 \\
\hline 17 & 2 & Ethyl a-aminoacetate hydrochloride & 2-Carboxy-4,5-dihydro-6,6-dimethyl-pyran[b-4,3]naphtho[1,2-d] oxazole & refl & $3 \mathrm{~h}$ & 43.6 & 175 \\
\hline 18 & 3 & Glycine/Pyridine & 5,5-Dimethyl-4-hydroxy-furan[b-4,3]naphtho[1,2-d] oxazole & refl & $17 \mathrm{~h}$ & 25 & 117 \\
\hline 19 & 3 & 2-Hydroxybenzaldehyde $/ \mathrm{NH}_{4} \mathrm{OAc}$ & 5,5-Dimethyl-2-(2'-hydroxyphenyl)-4-hydrofuran[b-4,3]naphtho[1,2-d] oxazole & refl & $1 / 2 \mathrm{~h}$ & 70 & 207 \\
\hline 20 & 1 & Glycine/ $\mathrm{NaHCO}_{3}$ & 5-Hydroxy-4-(2'-methyl-1'-propenyl)-naphtho[1,2-d] oxazole & $\mathrm{rt}$ & $7 \mathrm{~d}$ & 60 & 175 \\
\hline 21 & 20 & Diazomethane & 4-(2'-Methyl-1'-propenyl)-5-methoxynaphtho[1,2-d] oxazole & $6^{\circ} \mathrm{C}$ & $2 \min$ & 99 & $-\mathrm{f}$ \\
\hline 22 & 1 & Benzaldehyde/ $/ \mathrm{NH}_{4} \mathrm{OAc}$ & 5-Hydroxy-4-(2'-methyl-1'-propenyl)-2-phenyl-naphtho[1,2-d] oxazole & refl & $2 \mathrm{~d}$ & 32 & 168 \\
\hline \multirow[t]{2}{*}{23} & 22 & Diazomethane ${ }^{4}$ & 2-Phenyl-4-(3'-methyl-1'-propenyl)-5-methoxynaphtho[1,2-d] oxazole & $-10^{\circ} \mathrm{C}$ & $8 \mathrm{~h}$ & 100 & 72 \\
\hline & & naphthoimidazoles (route III) $^{b}$ & & & & & \\
\hline$\overline{24}$ & 2 & 3-Indolylaldehyde/ $\mathrm{NH}_{4} \mathrm{OAc}$ & 3,4-Dihydro-6,6-dimethyl-6H-2-(3'-indolyl)-pyran[b-4,3]naphtho[1,2-d] imidazole & refl & $4 \mathrm{~h}$ & 56 & 276 \\
\hline 25 & 2 & Benzaldehyde $/ \mathrm{NH}_{4} \mathrm{OAc}$ & 4,5-Dihydro-6,6-dimethyl-6H-2-phenyl-pyran[b-4,3]naphtho[1,2-d] imidazole & refl & $2 \mathrm{~h}$ & 78 & $281^{\mathrm{g}}$ \\
\hline 26 & 2 & 2-Methoxybenzaldehyde/ $\mathrm{NH}_{4} \mathrm{OAc}$ & 4,5-Dihydro-6,6-dimethyl-6H-2-(2'-methoxyphenyl)-pyran[b-4,3]naphtho[1,2-d] imidazole & refl & $2 \mathrm{~h}$ & 72 & $230^{\mathrm{h}}$ \\
\hline 27 & 2 & 3-Methoxybenzaldehyde/ $\mathrm{NH}_{4}^{4} \mathrm{OAc}$ & 4,5-Dihydro-6,6-dimethyl-6H-2-(3'-methoxyphenyl)-pyran[b-4,3]naphtho[1,2-d] imidazole & refl & $1.5 \mathrm{~h}$ & 77 & 153 \\
\hline 28 & 2 & 4-Methoxybenzaldehyde/ $\mathrm{NH}_{4}^{+} \mathrm{OAc}$ & 3,4-Dihydro-6,6-dimethyl-6H-2-(4'-methoxyphenyl)-pyran[b-4,3]naphtho[1,2-d] imidazole & refl & $1 \mathrm{~h}$ & 63 & 230 \\
\hline 29 & 2 & 2-Nitrobenzaldehyde/ $\mathrm{NH}_{4} \mathrm{OAc}^{4}$ & 3,4-Dihydro-6,6-dimethyl-6H-2-(2'-nitrophenyl)-pyran[b-4,3]naphtho[1,2-d] imidazole & refl & $1 / 2 \mathrm{~h}$ & 95 & 160 \\
\hline 30 & 2 & 3-Nitrobenzaldehyde/ $\mathrm{NH}_{4}^{4} \mathrm{OAc}$ & 3,4-Dihydro-6,6-dimethyl-6H-2-(3'-nitrophenyl)-pyran[b-4,3]naphtho[1,2-d] imidazole & refl & $1 \mathrm{~h}$ & 95 & 255 \\
\hline 31 & 2 & 4-Nitrobenzaldehyde/ $\mathrm{NH}_{4}^{+} \mathrm{OAc}$ & 3,4-Dihydro-6,6-dimethyl-6H-2-(4'-nitrophenyl)-pyran[b-4,3]naphtho[1,2-d] imidazole & refl & $3 \mathrm{~h}$ & 95 & 261 \\
\hline 32 & 2 & 2-Fluorobenzladehyde/ $\mathrm{NH}_{4} \mathrm{OAc}$ & 4,5-Dihydro-6,6-dimethyl-6H-2-(2'-fluorophenyl)-pyran[b-4,3]naphtho[1,2-d] imidazole & refl & $3 / 4 \mathrm{~h}$ & 85 & 195 \\
\hline 33 & 2 & 3-Fluorobenzaldehyde $/ \mathrm{NH}_{4}^{4} \mathrm{OAc}$ & 4,5-Dihydro-6,6-dimethyl-6H-2-(3'-fluorophenyl)-pyran[b-4,3]naphtho[1,2-d] imidazole & refl & $1 \mathrm{~h}$ & 89 & 238 \\
\hline 34 & 2 & 3-Chlorobenzaldehyde/ $\mathrm{NH}_{4}^{4} \mathrm{OAc}$ & 4,5-Dihydro-6,6-dimethyl-6H-2-(3'-chlorophenyl)-pyran[b-4,3]naphtho[1,2-d] imidazole & refl & $1.5 \mathrm{~h}$ & 83 & 234 \\
\hline 35 & 2 & 3,4-Methylenedioxybenzaldehyde/ $\mathrm{NH}_{4} \mathrm{OAc}$ & 3,4-Dihydro-6,6-dimethyl-6H-2-(3',4'-methylenedioxy)-pyran[b-4,3]naphtho[1,2-d] imidazole & refl & $1.5 \mathrm{~h}$ & 30 & 248 \\
\hline \multirow[t]{2}{*}{36} & 3 & 2-Hydroxybenzaldehyde/ $\mathrm{NH}_{4} \mathrm{OAc}$ & 5,5-Dimethyl-4-hydro-2-(2’-hydroxyphenyl)-furan[b-4,3]naphtho[2,1-d] imidazole & refl & $0.5 \mathrm{~h}$ & 29 & $224^{\mathrm{g}}$ \\
\hline & & phenoxazine (route IV) ${ }^{b}$ & & & & & \\
\hline \multirow[t]{2}{*}{$\overline{37}$} & 1 & 2-Aminophenol & 6-(3’-Methyl-2-butenyl)-benzo[e]-5oxa-2H-naphtho[2,1-b] phenoxazine & refl & $2 \mathrm{~h}$ & 70 & 140 \\
\hline & & dihydro indole $(\text { route } \mathbf{V})^{b}$ & & & & & \\
\hline \multirow[t]{2}{*}{38} & 2 & $\mathrm{NaOH} / \mathrm{NH}_{4} \mathrm{OH}$ & 3H,11H-3a,7a-Dihydroxy-10-methyl-benzo[6,7]pyran[b-5,4] indole & $\mathrm{rt}$ & $2 \mathrm{~h}$ & 72 & $236^{\mathrm{g}}$ \\
\hline & & cyclopentenes (routes VI \& VIII) $^{\text {b }}$ & & & & & \\
\hline$\overline{39}$ & 3 & Acetylacetone/NaOH & 5H-7-Acetyl-9,9-dimethyl-4b-hydroxy-8-hydro-6-oxa cyclopenta[3,4]naphtho[1,2-b] furane & $\mathrm{rt}$ & $12 \mathrm{~h}$ & 96 & $204^{\mathrm{g}}$ \\
\hline 40 & 3 & Ethyl acetoacetate $/ \mathrm{NaOH}$ & 5H-7-Carboxyethyl-9,9-dimethyl-4b-hydroxy-8-hydro-6-oxacyclopenta[3,4]naphtho[1,2-b] furane & $\mathrm{rt}$ & $12 \mathrm{~h}$ & 75 & 162 \\
\hline 41 & 2 & Acetylacetone/NaOH & $5 \mathrm{H}, 10 \mathrm{H}$-7-Acetyl-10,10-dimethyl-8,9-dihydro-4b-hydroxy-6-oxacyclopenta[3,4]naphtho[1,2-b] pyrane & $\mathrm{rt}$ & $12 \mathrm{~h}$ & 98 & 146 \\
\hline 42 & 2 & Ethyl acetoacetate $/ \mathrm{NaOH}$ & 5H,10H-7-Carboxyethyl-10,10-dimethyl-8,9-dihydro-4b-hydroxy-6-oxacyclopenta[3,4]naphtho[1,2-b] pyrane & rt & $12 \mathrm{~h}$ & 85 & $269^{\mathrm{g}}$ \\
\hline 43 & 39 & $\mathrm{H}^{+}$ & 5H-7-Acetyl-5-dihydro-9,9-dimethyl-8-hydro-6-oxacyclopenta[3,4]naphtho[1,2-b] furane & refl & $2 \mathrm{~h}$ & 95 & $250^{\mathrm{g}}$ \\
\hline \multirow[t]{2}{*}{44} & 42 & $\mathrm{H}^{+}$ & 5H-10H-7-Acetyl-5-dihydro-8,9-dihydro-10,10-dimethyl-6-oxacyclopenta[3,4]naptho[1,2-b] pyrane & refl & $2 \mathrm{~h}$ & 96 & $228^{\mathrm{g}}$ \\
\hline & & pyran (route VII) $^{\text {b }}$ & & & & & \\
\hline$\overline{45}$ & 39 & Acetic acid & 2H-3-Acetoxy-4-acetyl-6,6-dimethyl-5-hydrofuran[b'-1,2]naphtho[4,3-b]pyrane & $\mathrm{rt}$ & $18 \mathrm{~h}$ & 90 & 157 \\
\hline 46 & 41 & Acetic acid & 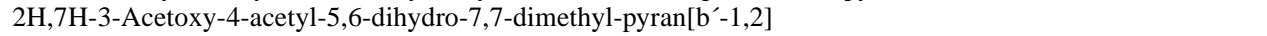 & $\mathrm{rt}$ & $18 \mathrm{~h}$ & 85 & 138 \\
\hline
\end{tabular}

\#: product; ${ }^{\mathrm{a}} \mathrm{Q}=$ starting quinone; ${ }^{\mathrm{b}} \mathrm{see}$ Scheme 1 ; ${ }^{\mathrm{t}}$ the derivatives were recrystallized from hexane:acetone $(9: 1)$; ${ }^{\mathrm{d}}$ reflux; ${ }^{\mathrm{e}}$ room temperature; ${ }^{\mathrm{f}}$ pale oil; ${ }^{\mathrm{g}} \mathrm{With}$ decomposition; ${ }^{\mathrm{h}}$ with sublimation 
compound and the yields are the following: for 26: 2 methoxybenzaldehyde, $2 \mathrm{~h}, 257.8 \mathrm{mg}$ (72\%); 27: 3methoxybenzaldehyde, $1.5 \mathrm{~h}, 275.7 \mathrm{mg}$ (77\%); 32: 2fluorobenzaldehyde, $45 \mathrm{~min}, 294.1 \mathrm{mg}$ (85\%); 33: 3fluorobenzaldehyde, $1 \mathrm{~h}, 308.0 \mathrm{mg}(89 \%)$; 34: 3chlorobenzaldehyde, $1.5 \mathrm{~h}, 302.1 \mathrm{mg}(83 \%)$.

The physical and spectral data of compounds 26, 27, 32-34 are given in Table 1 . In Table 2, the nomenclature and reaction conditions of all the compounds synthesised and assayed so far (present study plus refs 73 and 82).

\section{Trypanocidal activity}

Stock solutions of $\mathbf{2}$ and of the naphthoimidazole derivatives were prepared in dimethylsulfoxide (DMSO), with the final concentration of the latter in the experiments never exceeding $0.1 \%$. Experiments showed that in concentrations of up to $0.5 \%$, DMSO had no deleterious effect on the parasites. Bloodstream forms were obtained at the peak of parasitaemia from albino mice injected intraperitoneally with $10^{5}$ trypomastigotes of the Y strain \#83. Freshly isolated parasites were resuspended in Dulbecco's modified Eagle medium (DME) to a final parasite concentration of $5.10^{6}$ cells $/ \mathrm{mL}$. This suspension $(100 \mu \mathrm{L})$ was added in a volume ratio $1: 1$ to the drugs, also diluted in DME, and the mixture was then incubated at $4^{\circ}$ $\mathrm{C}$ in the presence $5 \%$ normal mouse blood. Some experiments were performed in DME without addition of blood. Parasites, both untreated and treated with crystal violet $(\mathrm{CV})$ were used as controls ${ }^{79}$. Cell counts were performed after $24 \mathrm{~h}$ of incubation in the presence of the drugs, with a Neubauer chamber. The drug concentration corresponding to $50 \%$ parasite lysis was expressed as the $\mathrm{ED}_{50}$, and the index of variation $\left(I V=\mathrm{ED}_{50}\right.$ crystal violet/ $\mathrm{ED}_{50}$ test substance) was obtained by the ratio of $\mathrm{ED}_{50} / 24 \mathrm{~h}$ of the standard $\mathrm{CV}$ in relation to the corresponding value of the assayed compound. So, $I V>1$ indicates activity higher than that of $\mathrm{CV}$, while $I V<1$, lower activity.

\section{Acknowledgments}

We are grateful to Dr. Walter B. Mors for comments and suggestions. This research was supported by grants from the Conselho Nacional de Desenvolvimento Científico e Tecnológico (CNPq), Programa de Apoio à Pesquisa Estratégica em Saúde (PAPES/FIOCRUZ), Fundação Carlos Chagas Filho de Amparo à Pesquisa do Rio de Janeiro (FAPERJ), and Fundação Universitária José Bonifácio/UFRJ.

\section{References}

1. Arenas, P. J. Ethnopharmacol. 1987, 21, 279.

2. Bastien, J. W. J. Ethnopharmacol. 1983, 8, 97.

3. Brunmark, A.; Cadenas, E. Free Radical Biol. Med. 1989, 7, 435.

4. Monks, T. J.; Hanslik, R. P.; Cohen, G. M.; Ross, D.; Graham, D. G. Toxicol. Appl. Pharmacol. 1992, 112, 2.

5. Munday, R.; Smith, B. L.; Munday, C. M. Free Radical Biol. Med. 1995, 19, 759.

6. Powis, G. Pharmacol. Ther. 1987, 35, 57.

7. O'Brien, P. J. Chem-Biol. Interact. 1991, 80, 1.

8. Koster, A. S. Pharm. Weekl. 1991, 13, 123.

9. Munday, R. Free Radical Res. 2000, 32, 245.

10. Cruz, F. S.; Gilbert, B.; Lopes, J. N.; Pinchin, R.; Pinto, A. V. Rev. Latinoamer. Quím. 1977, 8, 138.

11. Lopes, J. N.; Cruz, F. S.; DoCampo, R.; Vasconcellos, M. E.; Sampaio, M. C. R.; Pinto, A. V.; Gilbert, B. Ann. Trop. Med. Parasitol. 1978, 72, 523.

12. Pinto, A. V.; Pinto, M. C. F. R.; Gilbert, B.; Pelegrino, J.; Mello, R. T. Trans. Roy. Soc. Trop. Med. Hyg. 1977, $71,133$.

13. Pinto, A. V.; Pinto, M. C. F. R.; Lagrota, M. H.; Wigg, M. D.; Aguiar, A. N. Rev. Latinoamer. Microbiol. 1987, $29,15$.

14. Santana-Silva, J.; Ferrioli Filho, F.; Kanesiro, M. M.; Ferreira, V. F.; Santos, S. C.; Neves-Pinto, C.; Fonseca, J. L.; Mizrahy, H. E.; Gilbert, B.; Pinto, M. C. F. R.; Ribeiro, F. W.; Pinto, A. V. Mem. Inst. Oswaldo Cruz 1992, 87, 345.

15. Gonçalves Lima, O.; D’Albuquerque, I. C.; Lima, C. G.; Maia, M. H. D. Rev. Inst. Antibiot. (Recife) 1962, 4, 3 .

16. Gonçalves Lima, O.; Coelho, J. S.; D’Albuquerque, I. C.; Mello, J. F.; Martins, D. G.; Lacerda, A. L.; Moraes e Souza, M. A. Rev. Inst. Antibiot. (Recife) 1971, 11, 21.

17. D’Albuquerque, I. C.; Maciel, M. C. N.; Schuler, A. R.; De Araújo, M. C.; Medeiros Maciel, G.; Cavalcanti, M. S. B.; Gimino Martins, D.; Lins Lacerda, A. Rev. Inst. Antibiot. (Recife) 1972, 12, 31.

18. Consolação, M.; Linardi, F.; de Oliveira, M. M.; Sampaio, M. R. J. Med. Chem. 1975, 18, 1159.

19. Sieber, S. M.; Mead, J. A.; Adamson, R. H. Cancer Treat. Rep. 1976, 60, 1127.

20. Rao, M. M.; Kingston, D. G. I. J. Nat. Prod. 1982, 45,600 . 
21. Houghton, P. J.; Photiou, A.; Uddin, S.; Shah, P.; Browning, M.; Jackson, S. J.; Retsas, S. Planta Med. 1994, 60, 430.

22. Dinnen, R. D.; Ebisuzaki, K. Anticancer Res. 1997, 17, 1027.

23. De Almeida, E. R.; da Silva Filho, A. A.; dos Santos, E. R.; Lopes, C. A. J. Ethnopharmacol. 1990, 29, 239.

24. Guiraud, P.; Steiman, R.; Campos-Takaki, G. M.; Seigle-Murandi. F.; Simeon de Buochberg, M. Planta Med. 1994, 60, 373.

25. Binutu, O. A.; Adesogan, K. E.; Okogun, J. I. Planta Med. 1996, 62, 352.

26. Gafner, S.; Wolfender, J. L.; Nianga, M.; StoeckliEvans, H.; Hostettmann, K. Phytochemistry 1996, 42, 315.

27. Lagrota, M. H.; Wigg, M. D.; Aguiar, A. N.; Pinto, A. V.; Pinto, M. C. F. R. Rev. Latinoam. Microbiol. 1986, 28, 221.

28. Santos, M. G. M.; Lagrota, M. H. C.; Wigg, M. D.; Miranda, M. M. F; Pinto, A.V.; Pinto, M. C. F. R. Rev. Bras. Farm. 1992, 73, 78.

29. Fieser, L. F.; Berliner, E.; Bondhus, F. J. Am. Chem. Soc. 1948, 70, 313.

30. Li, C. J.; Wang, C.; Pardee, A. B. Cancer Res. 1995, $55,3712$.

31. Dolan, M. E.; Frydman, B.; Thompson, C. B.; Diamond, A. M.; Garbiras, B. J.; Safa, A. R.; Beck, W. T.; Marton, L. J. Anticancer Drugs 1998, 9, 437.

32. Lai, C. C.; Liu, T. J.; Ho, L. K.; Don, M. J.; Chau, Y. P. Histol. Histopathol. 1998, 13, 89.

33. Tang, D. G.; Porter, A. T. Prostate 1997, 32, 284.

34. Planchon, S. M.; Wuerzberger-Davis, S. M.; Pink, J. J.; Robertson, K. A.; Bornmann, W. G.; Boothman, D. A. Oncol. Rep. 1999, 6, 485.

35. Manna, S. K.; Gad, Y. P.; Mukhopadhyay, A.; Aggarwal, B. B. Biochem. Pharmacol. 1999, 57, 763.

36. Huang, L.; Pardee, A. B. Mol. Med. 1999, 5, 711.

37. Pink, J.J.; Wuerzberger-Davis, S.; Tagliarino, C.; Planchon, S. M.; Yang, X. H.; Froelich, C. J.; Boothman, D. A. Exp. Cell Res. 2000, 255, 144.

38. Li, C. J.; Averboukh, L.; Pardee, A. B. J. Biol. Chem. 1993, 268, 22463.

39. Weller, M.; Winter, S.; Schmidt, C.; Esser, P.; Fontana, A.; Dichgans, J.; Groscurth, P. Int. J. Cancer 1997, 73, 707.

40. Frydman, B.; Marton, L. J.; Sun, J. S.; Neder, K.; Witiak, D. T.; Liu, A. A.; Wang, H. M.; Mao, Y.; Wu, H. Y.; Sanders, M. M.; Liu, L. F. Cancer Res. 1997, 57, 620.

41. Chau, Y. P.; Shiah, S. G.; Don, M. J.; Kuo, M. L. Free Radical Biol. Med. 1998, 24, 660.
42. Bailly, C. Curr. Med. Chem. 2000, 7, 39.

43. Li, C. J.; Li, Y. Z.; Pinto, A. V.; Pardee, A. B. Proc. Natl. Acad. Sci. (USA) 1999, 96, 13369.

44. Boothman, D. A.; Greer, S.; Pardee, A. B. Cancer Res. 1987, 47, 5361.

45. Boothman, D. A.; Pardee, A. B. Proc. Natl. Acad. Sci. (USA) 1989, 86, 4963.

46. WHO. Thirteenth Programme Report UNDP/TDR, Geneve, 1997.

47. Hoare, C. A.; Wallace, F. G. Nature 1966, 244, 69.

48. Brener, Z.; Andrade, Z.; Barral-Netto, M. Trypanosoma cruzi e Doença de Chagas, Guanabara Koogan, Rio de Janeiro, 1999.

49. Dias, J. C. P. In Trypanosoma cruzi e Doença de Chagas; Brener, Z.; Andrade, Z. A.; Barral-Netto, N. Eds., Guanabara Koogan, Rio de Janeiro, 1999, p. 48.

50. Schofield, C. J.; Dias, J. C. P. Adv. Parasitol. 1999, 42,1 .

51. Medrano-Mercado, N.; Luz, M. R. M. P.; Torrico, F.T.; Tapia, G. T.; van Leuven, F.; Araujo-Jorge, T.C. Am. J. Trop. Med. Hyg. 1996, 54, 154.

52. Wendel, S.; Dias, J. C. P. In Chagas'Disease (American trypanosomiasis): Its Impact on Transfusion and Clinical Medicine; Wendel, S.; Brener, Z.; Camargo, E. C.; Rassi, A. Eds.; ISBT, São Paulo, 1992, p. 103.

53. Schmunis, G. A. In PAHO Chagas Disease and the Nervous System. Scientific Publ n 547, 1994, p. 3.

54. WHO. Report UNDP/WB/TDR, Geneve, 1984.

55. Thomas, S. M.; McPhee, D. G. Mutation Res. 1984, 140, 165.

56. Gutteridge, W. E. Int. J. Parasitol. 1987, 17, 121.

57. Fairlamb, A. H. Medicina 1999, 59, 1797.

58. De Castro, S. L. Acta Trop. 1993, 53, 83.

59. Urbina, J. A. J. Mol. Med. 1999, 77, 332.

60. Stoppani, A. O. M. Medicina 1999, 59, 147.

61. DoCampo, R.; Lopes, J. N.; Cruz, F. S.; de Souza. W. Exp. Parasitol. 1977, 42, 142.

62. DoCampo, R.; Cruz, F. S.; Boveris, A.; Muniz, R. P.; Esquivel, D. M. Arch. Biochem. Biophys. 1978, 186, 292.

63. Boveris, A.; DoCampo, R.; Turrens, J. F.; Stoppani, A. O. M. Rev. Asoc. Argent. Microbiol. 1977, 9, 54.

64. Boveris, A.; Stoppani, A. O. M.; DoCampo, R.; Cruz, F. S. Comp. Biochem. Physiol. 1978, 61C, 327.

65. Cruz, F. S.; DoCampo, R.; Boveris, A. Antimicrob. Agents Chemother. 1978, 14, 630.

66. DoCampo, R.; De Souza, W.; Cruz, F. S.; Roitman, I.; Cover, B.; Gutteridge, W. E. Z. Parasitenkd. 1978, 57, 189.

67. Goijman, S. G.; Stoppani, A. O. M. Rev. Argent. Microbiol. 1983, 15, 193. 
68. Gonçalves, A. M.; Vasconcellos, M. E.; DoCampo, R.; Cruz, F. S.; De Souza, W.; Leon, W. Mol. Biochem. Parasitol. 1980, 1, 167.

69. Pinto, A. V.; Pinto, M. C. F. R.; Oliveira, C. G. T. An. Acad. Brasil. Ciências 1982, 54, 107.

70. Pinto, A. V.; Pinto, M. C. F. R.; Aguiar, M. A.; Capella, R. S. An. Acad. Brasil. Ciências 1982, 54, 115.

71. Pinto, A. V.; Ferreira, V. F.; Pinto, M. C. F R.; Mayer, L. U. Synth. Commun. 1985, 15, 1181.

72. Pinto, A. V.; Ferreira, V. F.; Capella, R. S.; Gilbert, B.; Pinto, M. C. F. R.; Da Silva, J. S. Trans. Roy. Soc. Trop. Med. Hyg. 1987, 81, 609.

73. Pinto, A. V.; Neves-Pinto, C.; Pinto, M. C. F. R.; SantaRita, R. M.; Pezzella, C.; De Castro, S. L. ArzneimForsch. 1997, 47, 74.

74. Pinto, A. V.; Neves-Pinto, C.; Pinto, M. C. F. R.; Emery, F. S.; De Moura, K. C. G.; Carvalho, C. E. M.; Brinn, I. M. Heterocycles 1997, 45, 2431.

75. Pinto, M. C. F. R.; Pinto, A. V.; Oliveira, C. G. T. An. Acad. Brasil. Ciências 1980, 52, 481.

76. Lopes, C. C.; Lopes, R. S. C.; Pinto, A. V.; Costa, P. R. R. J. Heterocycl. Chem. 1984, 21, 621.

77. Ferreira, V. F.; Pinto, A. V.; Pinto, M. C. F. R.; Silva, M. M. J. Chem. Res.(S) 1987, 26.

78. Chaves, J. P.; Pinto, M. C. F. R.; Pinto, A. V. J. Braz. Chem. Soc. 1990, 1, 21.

79. De Castro, S. L.; Pinto, M. C. F. R.; Pinto, A. V. Microbios 1994, 78, 83.

80. Neves-Pinto, C.; Pinto, M. C. F. R.; Emery, F. S.; De Moura, K. C. G.; Pinto, A. V. An. Acad. Bras. Ciências 1997, 69, 15.

81. Neves-Pinto, C. Ph.D. Thesis, NPPN, Universidade Federal do Rio de Janeiro, 1998.

82. Neves-Pinto, C.; Dantas, A. P.; De Moura, K. C. G.; Emery, F. S.; Polequevitch, P. F.; Pinto, M. C. F. R.; De Castro, S. L.; Pinto, A. V. Arzneim-Forsch. 2000, 50, 1120 .

83. Silva, L. H. P.; Nussenszweig, V. Folia Clin. Biol. 1953, 20, 191.
84. Patai S. The Chemistry of the Quinonoid Compounds, John Wiley \& Sons, NY, 1983.

85. Goijman, S. G.; Stoppani, A. O. M. Arch. Biochem. Biophys. 1985, 240, 273.

86. Goulart, M. O. F.; Zani, C. L.; Tonholo, J.; Freitas, L. R.; Abreu, F. C.; Oliveira, A. B.; Raslan, D. S.; Starling, S.; Chiari, E. Bioorg. Med. Chem. Lett. 1997, 7, 2043.

87. Sepulveda-Boza, S.; Cassels, B. K. Planta Med. 1996, $62,98$.

88. Winkelmann, E.; Raether, W.; Sinharay, A. ArzneimForsch. 1978, 28, 351.

89. McCabe, R. E.; Araújo, F. G.; Remington, J. S. Am. J. Trop. Med. Hyg. 1983, 32, 960.

90. Chabala, J. C.; Waits, V. B.; Ikeler, T.; Patchett, A. A.; Payne, L.; Peterson, L. H.; Reamer, R. A.; Hoogsteen, K.; Wyvratt, M.; Hanson, W. L.; Fisher, M. H. Experientia 1991, 47, 51.

91. Nothemberg, M. S.; Takeda, G. K. F.; Najjar, R. J. Inorg. Biochem. 1991, 42, 217.

92. Blandon, R.; Johnson, C. M.; Sousa, O.; Leandro, I.; Guevara, J. F. Rev. Med. Panama 1993, 18, 94.

93. Molina Portela, M. P.; Fernandez Villamil, S. H.; Perissinotti, L. J.; Stoppani, A. O. M. Biochem. Pharmacol. 1996, 52, 1875.

94. Bernard, J.; Riou, G. In Biochemistry of Parasites and Host-Parasite Relationships; Van den Bossche, M. Ed.; Elsevier / North-Holland Biomedical Press; Amsterdam, 1976, p. 477.

95. Bernard, J.; Riou, G. Biochem. Biophys. Res. Comm. 1977, 77, 1189.

96. Bernard, J.; Riou, G. Biochemistry 1980, 19, 4197.

97. Douc-Rasy, S.; Kayser, A.; Riou, G. Biochem. Biophys. Res. Commun. 1983, 117, 1.

98. Douc-Rasy, S.; Kayser, A.; Riou G. EMBO J. 1984, 3,11 .

Received: November 14, 2000 Published on the web: May 16, 2001 